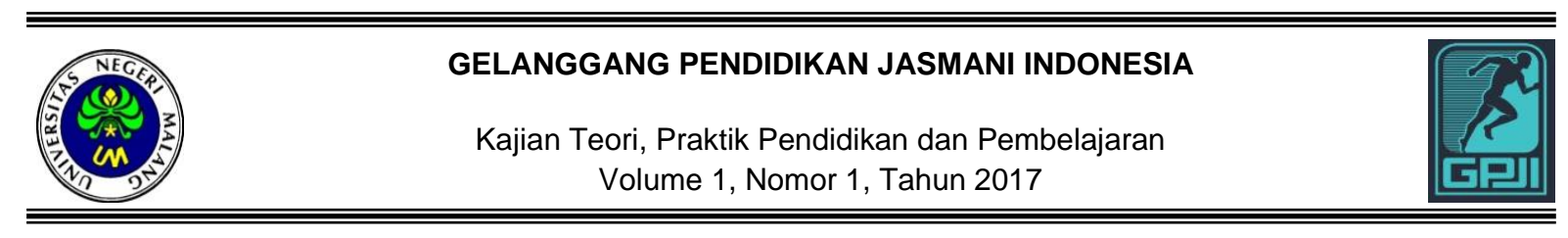

\title{
PENGEMBANGAN PERMAINAN AKU DAN HEWAN MENGGUNAKAN MULTIMEDIA INTERAKTIF UNTUK GURU ANAK USIA DINI
}

\author{
Ndaru Kukuh M. \\ Wasis D. Dwiyogo \\ Febrita Paulina Heynoek \\ Fakultas Ilmu Keolahragaan Universitas Negeri Malang \\ Email: ndarutaichou@yahoo.com
}

\begin{abstract}
This research is conducted with the aim of developing the game using interactive multimedia media to address issues about sport learning that arise in the early childhood education. Data were collected using a needs analysis using a questionnaire to 44 teachers spread over 8 kindergarten (TK). The result of product development game I and Animal using interactive multimedia for early chilhood teachers obtained the results: the result evaluation of preschool (PAUD) expert $81,73 \%$, the result evaluation of game expert 87,42 , the result evaluation of media expert $80,51 \%$, small group trial $80,41 \%$ it implies good result, large group trial 87,65 it shows very good result. So this product is fit for use.
\end{abstract}

Keywords: game, interactive multimedia, early childhood teachers.

\begin{abstract}
Abstrak: Tujuan penelitian ini adalah mengembangkan permainan aku dan hewan dengan menggunakan media multimedia interaktif untuk mengatasi masalah yang muncul dalam pembelajaran olahraga di jenjang Pendidikan Anak Usia Dini. Data dikumpulkan dengan menggunakan analisis kebutuhan menggunakan angket kepada 44 orang guru yang tersebar di 8 sekolah Taman Kanak-kanak (TK). Hasil pengembangan produk permainan aku dan hewan menggunakan multimedia interaktif untuk guru anak usia dini diperoleh hasil sebagai berikut: hasil evaluasi ahli pendidikan anak usia dini (PAUD) 81,73\%, hasil evaluasi ahli permainan 87,42\%, hasil evaluasi ahli media $80,51 \%$, hasil uji coba kelompok kecil $80,41 \%$ hasilnya baik, hasil uji coba kelompok besar $87,65 \%$ hasilnya sangat baik. Sehingga produk ini layak untuk digunakan.
\end{abstract}

Kata Kunci: permainan, multimedia interaktif, guru anak usia dini.

Usia dini merupakan ke-sempatan emas bagi anak untuk belajar, sehingga disebut dengan usia emas (golden age). Pada usia ini anak memiliki kemampuan untuk belajar yang luar biasa, khususnya pada masa kanak-kanak awal. Mengingat usia dini merupakan usia emas maka pada masa itu perkembangan anak harus dioptimal-kan. Perkembangan anak usia dini sifatnya holistik, yaitu dapat ber-kembang optimal apabila sehat badannya, cukup gizinya, dan dididik secara baik dan benar. Anak berkembang dari berbagai aspek yaitu berkembang fisiknya, baik motorik kasar maupun halus, berkembang aspek kognitif, aspek sosial, dan emosional (Mursid, 2015:122).

Pertumbuhan anak usia dini dan perkembangan anak usia dini perlu diarahkan pada peletakan dasar-dasar yang tepat bagi pertumbuhan dan perkembangan manusia seutuhnya. Pendidikan anak usia dini adalah pemberian upaya untuk menstimulasi, membimbing, mengasuh, dan memberikan kegiatan pembelajaran yang nantinya akan menghasilkan kemampuan dan ketrampilan anak.

Perkembangan aspek fisik merupakan dasar bagi kemajuan perkembangan berikutnya. Dengan meningkatnya pertumbuhan tubuh, baik menyangkut ukuran berat 
dan tinggi, maupun kekuatannya memungkinkan anak untuk lebih mengembangkan keterampilan fisiknya, dan eksplorasi terhadap lingkungannya dengan tanpa bantuan dari orang tuannya. Perkembangan sistem syaraf pusat memberikan kesiapan kepada anak untuk lebih dapat meningkatkan pemahaman dan penguasaan terhadap tubuhnya demikian merupakan pendapat dari Yusuf (2000:163). Menurut Yusuf (2000:164-165) menjelaskan "perkembangan fisik anak ditandai juga dengan berkembangnya kemampuan atau keterampilan motorik, baik yang kasar maupun yang lembut". Desmita (2005:129) berpendapat "perkembangan fisik pada masa anak-anak ditandai dengan mulai berkembangnya keterampilan motorik, baik kasar maupun halus". Baharom, dkk (2014:129), "Gross motor deve-lopment is an important element to be developed according to chronological age so that children will not fine difficulties to engage in more complex motor behavior at a higher age", dapat diartikan bahwa perkembangan motorik kasar adalah elemen penting yang berkembang berdasarkan kronologi usia sehingga anak tidak dapat mencari kesulitan untuk mengikutsertakan tingkah laku motorik yang lebih kompleks pada usia yang lebih tinggi. Dari beberapa pendapat ahli diatas dapat disim-pulkan bahwa perkembangan motorik pada masa anakanak sangat berperan untuk mempersiapkan motoriknya pada masa selanjutnya atau masa yang akan datang.

Pendidikan anak usia dini pada dasarnya meliputi seluruh upaya dan tindakan yang dilakukan oleh pendidik dan orang tua dalam proses perawatan, pengasuhan, serta pemberian pedidikan pada anak dengan menciptakan aura dan lingkungan di mana anak dapat mengeksplorasi pengalaman melalui cara mengamati, meniru, dan bereksperimen yang berlangsung se-cara berulang-ulang dan melibatkan seluruh potensi dan kecerdasan anak (Mursid, 2015: 15).

Pelaksanaan pendidikan anak usia dini dilakukan dengan berbagai prinsip dan pendekatan yaitu pem-belajaran berorientasi pada ke-butuhan anak, belajar melalui bermain, menggunakan media dan sumber belajar, berorientasi kepada prinsip perkembangan dan belajar anak (Yus, 2010:67).
Sedangkan menurut teori dari Mursid (2015:37) menjelaskan bahwa proses pembelajaran pada anak usia dini haruslah didasarkan pada prinsip-prinsip perkembangan anak usia dini, yaitu (1) proses belajar pada anak usia dini harus dilaksanakan berdasarkan prinsip belajar melalui bermain; (2) proses kegiatan belajar anak usia dini dilaksanakan dalam lingkungan yang kondusif dan inovatif; (3) proses kegiatan belajar anak usia dini dilaksanakan dengan pendekatan tematik dan terpadu; (4) proses kegiatan belajar anak usia dini harus diarahkan pada pengem-bangan potensi kecerdasan secara menyeluruh dan terpadu.

Potensi yang dimiliki anak usia dini merupakan bawaan sejak lahir untuk dikembangkan di lingkungannya. Anak memiliki kemampuan yang menyebar dalam beberapa dimensi pengembangan (Yus, 2010: 70). Menurut teori yang dikemukakan Gardner (1983) salah satu dimensi pengembangan yang dapat dikembangkan adalah Kines-tesis Jasmani (Bodily Kinesthetic Intelligence) yang merupakan ke-mampuan menggunakan seluruh tubuh dan komponennya untuk me-mecahkan permasalahan, membuat sesuatu, atau menggunakan beberapa macam produksi, dan koordinasi anggota tubuh dan pikiran untuk menyempurnakan penampilan fisik. Kecerdasan kinestesis jasmani digambarkan melalui ciriciri, seperti mudah: (1) bergerak dengan daya kontrol tubuh yang baik, seperti berjalan, lari, lompat, loncat, me-nangkap, dan melempar; (2) menyentuh objek disekitanya; (3) memanipulasi benda, seperti kursi digu-nakan sebagai mobil; (4) responsif terhadap lingkungan, misalnya menggerakkan tubuh atau tangan saat merasakan angin bertiup; (5) berpikir mekanis; (6) mengingat apa yang dilakukan; (7) membuat kerajinan tangan; dan (8) berolahraga.

Dimensi pengembangan dan kecerdasan anak usia 5-6 tahun antara lain: (1) melempar bola ke arah yang ditetapkan; (2) melempar bola ke arah yang ditetapkan; (3) menangkap dan melempar bola dengan cepat; (4) gerakan berpindah dengan zigzag; (5) menggunting pada satu garis; (6) menenmpel, menggambar, mewarnai; (7) me-nyusun puzzle dengan bentuk kompleks (amazing); (8) loncat (jumping) jarak satu meter; (9) lompat (hopping) setinggi $40 \mathrm{~cm}$; 
Ndaru Kukuh M, Pengembangan Permainan Aku dan Hewan Menggunakan Multimedia Interaktif untuk Guru Anak Usia Dini

(10) melompat untuk menjangkau benda ke atas atau ke depan; (11) mengayuh sepeda dengan cepat; (12) menyepak (kicking) bola ke arah yang ditentukan; (13) membuat tanda dengan menggunakan jari; (14) memotong makanan yang mudah di-potong dengan pisau; (15) mengikat tali; (16) berlari dengan seimbang dan dapat berhenti secara tiba-tiba; (17) mengancing baju; (18) menggunakan kuas, pensil, krayon untuk membuat coretan, bentuk, dan gambar (Yus, 2010:78).

Anak usia dini memiliki kubutuhan gerak yang sesuai dengan usia perkembangannya. Dalam usia perkembangan anak usia dini ke-butuhan gerak dikategorikan ber-dasarkan kelompok usia, hal ini dijelaskan oleh Gallahue (1996:25), "As a child develops, gradual shifts or increments in level of functioning occur in the stability, locomotor, and manipulative categories of movement behavior". Dari pernyataan tersebut dapat diartikan bahwa anak-anak berkembang secara berangsur-angsur pada tingkat usia dikategorikan dalam perkembangan lokomotor, non lokomotor, dan manipulatif. Kebutuhan gerak anak usia 5-6 tahun pada perkembangan lokomotor, non lokomotor, dan manipulatif, yaitu: (1) berlari dengan kemampuan yang dipilih kecepatan lari meningkat; (2) meloncat dengan kemampuan yang dipilih meloncat dengan jarak (tiga kaki), meloncat dengan ketinggian (satu kaki), dan pola meloncat seperti orang dewasa; (3) melompat dengan kemampuan yang dipilih melompat 8-10 kali dengan kaki yang sama, melompat dengan jarak 50 kaki dengan waktu 11 detik, lompat terampil dengan irama yang teratur; (4) berderap dengan kemampuan yang dipilih berderap dengan terampil; (5) berpacu dengan kemampuan yang dipilih berpacu dengan terampil; (6) melempar dengan kemampuan yang dipilih pola melempar putra lebih baik dari pola melempar putri, pola melempar seperti orang dewasa; (7) menendang kemampuan yang dipilih pola menendang seperti orang dewasa (menendang bola sepenuh-nya); (8) menyerang dengan kemam-puan yang dipilih menyerang menggunakan berat badan, pola menyerang seperti orang dewasa; (9) keseimbangan dinamis dengan kemampuan yang dipilih mempu melakukan guling depan; (10) keseimbangan statis dengan kemam-puan yang dipilih berdiri menggu-nakan satu kaki 3-5 detik, menyeimbangkan tubuh dengan 3 titik dasar; (11) gerakan axial dengan kemampuan yang dipilih merupakan peningkatan dari gerakan dasar yang disebut gerakan manipulatif yaitu melempar, menangkap, menendang menyerang, dan aktivitas lainnya (Gallahue, 1996:26-28).

Dalam kurikulum 2013 Pendidikan Anak Usia Dini (PAUD), salah satu materi yang harus dipelajari oleh anak usia 5-6 tahun adalah gerak motorik kasar dan halus yang terdapat pada KI (kompetensi inti)-4 menunjukkan yang diketahui, dirasakan, dibu-tuhkan, dan dipikirkan melalui bahasa, musik, gerakan, dan karya secara produktif dan kreatif, serta mencerminkan perilaku anak berakhlak mulia dengan menggunakan KD (kompetensi dasar) 4.3 Menggunakan anggota tubuh untuk pengembangan motorik kasar dan halus dan KD (kompetensi dasar) 4.8 Menyajikan berbagai karya yang berhubungan dengan lingkungan alam (hewan, tanaman, cuaca, tanah, air, batubatuan, dII) dalam bentuk gambar, bercerita, bernyanyi, dan gerak tubuh (Sumber: Peraturan Menteri Pendidikan dan Kebudayaan Republik Indonesia, Kurikulum 2013 Pendidikan Anak Usia Dini).

Banyak metode yang dapat digunakan dalam melakukan gerak tubuh salah satunya adalah ben-tuk permainan. Karena permainan merupakan kegiatan anak-anak sepanjang hari karena bagi anak bermain adalah hidup dan hidup adalah permainan (Mayesty dalam Mursid, 2015:37).

Menurut Furqon (2006:2) menjelaskan "bermain adalah akti-vitas yang menyenangkan, serius, dan sukarela, di mana anak berada dalam dunia yang tidak nyata atau sesungguhnya. Bermain bersifat menyenangkan karena anak diikat oleh sesuatu yang menyenangkan, dengan tidak banyak memerlukan pemikiran. Yus (2010:61), "bermain sesungguhnya adalah sarana terbaik bagi seorang anak untuk belajar secara aktif dan menyenagkan". Menurut Thobroni \& Mumtaz (2011:41), menyatakan "bermain adalah bersenang-senang, melakukan sesuatu dengan senang dan menyenangkan diri". Smith (2013:1), "Play is often defined as activity done for its own sake, characterized by means rather than ends (the process is more important than any end point or goal), flexibility (objects are 
put in new combinations or roles are acted out in new ways), and positive affect (children often smile, laugh, and say they enjoy it)", dapat diartikan bahwa bermain sering didefinisikan sebagai kegiatan yang dilakukan untuk kepentingan sendiri, ditandai dengan cara daripada hasil-nya (proses lebih penting daripada titik akhir atau tujuan), fleksibilitas (objek yang dimasukkan ke dalam kombinasi baru atau peran yang bertindak dalam cara-cara baru), dan berdampak positif (anak-anak sering tersenyum, tertawa, dan mengatakan mereka menikmatinya). Menurut Huang (2013:14) ber-pendapat "Play can be seen as both an effect of and on culture because children's play reproduces and also changes culture over time", yang dapat diartikan bermain dapat dilihat baik sebagai efek dan budaya karena saat anak-anak bermain mereka mereproduksi dan juga perubahan akibat dari budaya dari waktu ke waktu. Berdasarkan pendapat ahli diatas dapat disimpulkan bahwa bermain adalah segala aktifitas yang bersifat menyenangkan dan dapat men-dorong anak untuk belajar tanpa mempertimbangkan hasil akhir.

Menurut Furqon (2006:1) menjelaskan "permainan merupakan suatu laboratorium di mana anak dapat menerapkan ketrampilan baru yang dipelajari dengan cara yang tepat. Banyak permainan yang dapat membantu mengembangkan ke-lompok otot-otot besar dan mening-katkan kemampuan berlari, lari berkelok kelok, mulai dan berhenti berlari di bawah kontrol dengan berbagi kesempatan dengan teman yang lain.

Permainan dimainkan dengan membutuhkan banyak keterikatan dan banyak energi, lebih kuat dan serius daripada bermain, dan lebih memungkinkan memberikan peng-hargaan terhadap pemenuhan dan keberhasilan. Oleh karena itu, permainan dapat didefinisikan se-bagai aktivitas yang dibatasi oleh aturan-aturan yang lengkap dan terdapat suatu kontes di antara para pemain agar supaya menghasilkan hasil yang dapat diprediksi. Dengan kata lain bahwa permainan adalah kontes sukarela yang didasari peraturan dan tujuan-tujuan yang dinyatakan dengan jelas, demikian pendapat Morris dan Stiehl dalam Furqon (2006:3). Menurut Rousseau dan Darwin dalam Monks, dkk (2006:132) berpendapat "permainan sebagai ulangan (rekapitulasi) bentuk-bentuk aktivitas yang dalam perkembangan jenis manusia pernah memegang peranan yang dominan". Sedangkan Desmita (2005:141) menjelaskan "permainan adalah salah satu bentuk aktivitas sosial yang dominan pada awal masa kanakkanak. Sebab, anak-anak menghabiskan lebih banyak waktunya di luar rumah bermain dengan teman-temannya dibanding terlibat dalam aktivitas lain". Berdasarkan pendapat ahli diatas dapat disimpul-kan bahwa permainan adalah aktivitas yang dominan padal masa kanak-kanak dimana anak dapat memperoleh ketrampilan baru dan aktivitas tersebut dibatasi dengan aturan-aturan yang disepakati.

Permainan Aku dan Hewan adalah bentuk permainan yang dirancang untuk anak usia 5-6 tahun berdasarkan kurikulum Pendidikan Anak Usia Dini 2013 yang tertera dalam Permendikbud Republik Indonesia Kompetensi Inti-4 Kom-petensi Dasar 4.3 dan 4.8 dengan bentuk pos/sirkuit dalam pelak-sanaannya. Dalam permainan aku dan hewan setiap gerakan yang dilakukan pada setiap pos/sirkuit adalah menirukan berbagai jenis gerakan hewan. Permainan aku dan hewan merujuk pada teori para ahli yang menjelaskan potensi yang dimiliki anak menyebar dalam beberapa dimensi pengembangan (Yus, 2010:70). Salah satu dimensi pe-ngembangan yang dapat dikem-bangkan adalah Kinestetis Jasmani (Bodily Kinesthetic Intelligence) yang merupakan kemampuan menggunakan seluruh tubuh dan komponennya untuk memecahkan permasalahan, membuat sesuatu, atau menggunakan beberapa macam produksi, dan koordinasi anggota tubuh dan pikiran untuk menyempurnakan penampilan fisik.

Terdapat 20 gerakan yang terbagi dalam tigak aspek dalam permainan aku dan hewan yaitu: (1) non lokomotor (burung, kelinci, siput, gajah, dan buaya); (2) lokomotor (anjing, harimau, kangguru, kancil I, kancil II, kuda, monyet, dan ular; (3) manipulatif (lempar bola, menendang bola, loncat susun puzzle, pindah selang, jalan diatas balok kayu, lempar tangkap bola, dan pindah bola.

Peran guru juga penting dalam proses perkembangan dan pembelajaran anak sesuai dengan yang tertulis dalam Permen- 
Ndaru Kukuh M, Pengembangan Permainan Aku dan Hewan Menggunakan Multimedia Interaktif untuk Guru Anak Usia Dini

diknas No. 58 tahun 2009 yang dimaksud dengan pendidik anak usia dini adalah profesional yang bertugas merenca-nakan, melaksanakan proses pembelajaran, serta me-lakukan pembimbingan, pengasuh, dan perlindungan anak didik (Muhammad, 2012: 79-80). Fakta yang terjadi dalam pembelajaran gerak di tingkat pendidikan anak usia dini pada fase pelaksanaan proses pembelajaran, guru menggunakan kurikulum sebagai dasar dalam pelaksanaan proses pembelajaran tetapi konsep perkembangan belajar gerak pada anak usia dini belum diterapkan sehingga pembelajaran yang diberikan selama ini belum berjalan semestinya. Seharusnya dalam pe-laksanaan proses pembelajaran disamping menggunakan kurikulum sebagai acuan guru harus mengerti tentang konsep belajar gerak pada anak usia dini sehingga potensi yang dimiliki anak dapat dikeluarkan dan dieksplorasi. Kesimpulannya guru tidak memiliki rujukan atau pe-ngetahuan tentang konsep gerak dasar pada anak usia dini.

Dibutuhkan media yang dapat membantu dan mempermudah dalam proses penyampaiannya dalam kegiatan pembelajaran. Ada banyak beragam media yang dapat digunakan untuk kegiatan pembelajaran salah satunya adalah media berbasis komputer. Kelebihan dari media berbasis komputer adalah pesan yang disampaikan dapat dibuat menarik dan mudah diakses oleh penerima pesan sedangkan kekurangannya adalah penerima pesan harus memiliki komputer dalam proses pembelajaran. Perkemba-ngan ilmu pengetahuan dan teknologi (IPTEK) semakin ber-kembang pesat pada era abad 21 ini ditandai dengan pesatnya produk dan pemanfaatan teknologi informasi. Berkembangnya ilmu dan teknologi, membawa perubahan pula pada learning matterial atau bahan belajar. Sebelum berkembangnya teknologi komputer bahan belajar yang pokok digunakan dalam dunia pendidikan adalah semua yang bersifat printed matterial, seperti halnya buku, modul, makalah, majalah, koran, tabloid, jurnal, hand out lifted, buklet, dan sebagainya yang semuanya meng-gunakan bahan tercetak (Darmawan, 2011: 54).

Adanya perubahan dalam bidang teknologi khususnya teknologi informasi, membawa paradigma baru pada learning matterial dan learning method. Produk TI dewasa ini telah memberikan alternatif berupa bahan belajar yang dapat digunakan dan diakses oleh peserta didik yang tidak dalam bentuk kertas, tetapi berbentuk CD, DVD, Flashdisk, dan lain-lain (Darmawan, 2011: 54).

Dari penelitian yang akan dilakukan dan memperkuat judul penelitian, peneliti melakukan kajian terhadap penelitian sebelumnya untuk memperoleh informasi apakah penelitian yang serupa pernah dilakukan atau tidak. Dari hasil kajian penelitian sebelumnya, peneliti me-nemukan kajian serupa yang pernah dilakukan oleh Bachtiar (2008) tentang pengembangan model permainan berbasis kecerdasan kines-tetik untuk taman kanak-kanak kelas B di TK Negeri pembina I Kota Malang. Dalam penelitiannya berfokus pada pengembangan pola permainan guna mengembangkan potensi kinestetik siswa dan hasilnya pada uji coba kelompok kecil diperoleh persentase 87,92 sedang-kan pada uji coba kelompok besar diperoleh persentase $92,08 \%$ hal tersebut menunjukkan bahwa model permainan dapat digunakan sebagai upaya mengembangkan kecerdasan kinestetik anak kelas B di TK Neger Pembina I Kota Malang. Penelitian serupa juga pernah dilakukan oleh Fantiro (2008) tentang pengembangan model permainan untuk meningkatkan kecerdasan kinestetik siswa taman kanak-kanak negeri pembina kecamatan kepanjen kabupaten malang. Dalam penelitiannya berfokus pada pengembangan model permainan yang bertujuan mengembangkan kecerdasan kinestetik siswa taman kanak-kanak dan hasilnya pada uji coba kelompok besar diperoleh persentase 91,19\% untuk kelompok $A$ dan $92,61 \%$ untuk ke-lompok $\mathrm{B}$ hal tersebut menunjukkan bahwa model permainan yang dikembangkan dapat dijadikan alter-natif untuk pembelajaran khususnya kecerdasan kinestetik. Selain penelitian yang dilakukan oleh Bachtiar dan Fantiro, penelitian serupa juga pernah dilakukan oleh Dwi W (2005) tentang pengembangan modul per-mainan gerak motorik kasar bagi guru TK Dharma Wanita di desa pringu kecamatan bululawang kabupaten malang. Dalam penelitiannya berfokus pada pengembangan kecerdasan gerak melalui permainan gerak motorik kasar dan hasilnya pada uji coba pengguna: (1) aspek kegunaan diperoleh rata-rata 3,58; 
(2) pada aspek ketepatan diperoleh ratarata 3,375; (3) aspek keefektifan diperoleh ratarata 3,16 ; (4) aspek keteraksanaan diperoleh rata-rata 3,46 ; (5) aspek kemenarikan diperoleh rata-rata 3,25 hal tersebut menunjukkan bahwa buku modul permainan gerak motorik kasar sangat berguna, mudah menarik dan akurat untuk dijadikan sebagai media pembelajaran permainan TK.

Berdasarkan hasil analisis kebutuhan berupa angket yang diberikan kepada 44 guru yang tersebar di 8 Taman Kanak-kanak (TK) yaitu TK Kemala Bhayangkari 12, TK Miftahul Ulum, RA As-saadah, TK Dharma Wanita Persatuan 2, TK Gaya Baru, RA Kalimosodo, TK Muta'alimin, TK Muslimat An-nur, maka diperoleh hasil: 1) 100\% menjawab menggunakan kurikulum 2013 dan $0 \%$ menjawab tidak menggunakan kurikulum 2013, 2) 33\% menjawab permainan yang selama ini dilakukan menarik dan $67 \%$ menjawab tidak menarik, 3) $100 \%$ menjawab gerak tubuh khususnya hewan disampaikan di TK dan 0\% menjawab tidak disampaikan di TK, 4) $28 \%$ menjawab permainan yang diberikan berjalan optimal dan $72 \%$ menjawab tidak optimal, 5) $100 \%$ menjawab setuju jika dikembangkan permainan baru yang berhubungan dengan gerak tubuh khususnya hewan dan $0 \%$ menjawab tidak setuju, 6) $100 \%$ menjawab di TK pernah menggunakan media dalam proses pembelajaran dan $0 \%$ menjawab tidak, (7) 19\% menjawab di TK pernah menggunakan media berbasis TI (Teknologi Informasi) dan $81 \%$ menjawab tidak pernah, (8) $100 \%$ menjawab setuju jika dikembangkan media berbasis TI (Teknologi Informasi) dan 0\% menjawab tidak.

Untuk mengatasi masalah-masalah diatas peneliti merujuk kurikulum 2013 PAUD kompetensi dasar 4.8 Menyajikan berbagai karya yang berhubungan dengan lingku-ngan alam (hewan, tanaman, cuaca, tanah, air, batu-batuan, dII) dalam bentuk gambar, bercerita, bernyanyi, dan gerak tubuh. Dari kompetesi dasar tersebut akan digunakan salah satu aspek yaitu hewan dalam bentuk gerak tubuh. Peneliti juga akan memberikan alternatif media pembelajaran berupa multimedia interaktif kepada guru karena pengetahuan guru terhadap perkembangan tek-nologi informasi masih terbatas dan guru membutuhkan media pem-belajaran yang digunakan pada era globalisasi ini salah satunya multi-media interaktif. Berdasarkan perma-salahan diatas peneliti menemukan solusi yaitu dengan mengembangkan permainan aku dan hewan menggu-nakan multimedia interaktif.

Berdasarkan latar belakang di atas dan kebutuhan akan permainan yang bertemakan hewan pada jenjang pendidikan anak usia dini, maka peneliti akan melakukan penelitian dan pengembangan yang berjudul "Pengembangan Permainan Aku dan Hewan Menggunakan Multimedia Interaktif untuk Guru Anak Usia Dini”.

Tujuan penelitian dan pe-ngembangan ini adalah mengem-bangkan permainan aku dan hewan dengan menggunakan media multimedia interaktif. Penelitian dan pengembangan yang dilakukan ada-lah untuk mengatasi masalah yang muncul dalam pembelajaran olahraga di jenjang Pendidikan Anak Usia Dini.

\section{METODE}

Metode yang digunakan dalam penelitian dan pengembangan permainan "aku" dan hewan meng-gunakan multimedia interaktif untuk guru anak usia dini ini, peneliti merujuk pada langkah-langkah yang dikemukakan oleh Lee \& Owen (2004:1) menggunakan lima tahap dalam pengembangannya, yaitu. (1) Analisis (langkah-langkah yang digunakan untuk mengkaji keadaan lapangan dengan tujuan apakah produk yang dikembangkan diterima atau tidak oleh subjek), (2) Desain (perancangan produk yang akan digunakan berdasarkan informasi yang telah didapatkan dari tahap analisis dan mengumpulkan bahan-bahan yang akan digunakan dalam pembuatan produk), (3) Pengem-bangan (dilakukan pengem-bangan produk sesuai dengan desain yang dibuat. Pada tahap ini dilakukan beberapa tahap, yaitu: pengemba-ngan, validasi ke ahli yang berhu-bungan dengan bidang terkait, dan revisi berdasarkan saran dari ahli), (4) Implementasi (tahap uji coba produk yang dilakukan kepada subjek uji coba), (5) Evaluasi (penilaian dilakukan dengan mengo-lah hasil dari validasi ahli dan uji coba kepada pengguna dengan tujuan untuk 
Ndaru Kukuh M, Pengembangan Permainan Aku dan Hewan Menggunakan Multimedia Interaktif untuk Guru Anak Usia Dini

mengetahui kelayakan produk yang dikembangkan)

Pengembangan produk ini dilakukan dalam beberapa tahap, yaitu: (1) Melakukan analisis, pada tahap ini dibagi menjadi needs assessment (pengumpulan data berupa angket analisis kebutuhan) dan front-end analysis (menganalisis data-data dan informasi yang benar-benar dibutuhkan. Pada tahap front-end analysis ada beberapa kegiatan yaitu audience analysis untuk menentukan target/sasaran yang akan memakai produk permainan aku dan hewan menggunakan multimedia interaktif, technology analysis untuk menentukan jenis tekhnologi (hard-ware dan software) yang dibutuhkan untuk pengembangan dan menjalankan multimedia interaktif permainan aku dan hewan, media analysis menentukan jenis media yang akan dikembangkan, dan extand-data ana-lysis untuk menentukan isi materi yang akan diterapkan dalam aplikasi, (2) Desain, merupakan tahap peran-cangan permainan aku dan hewan menggunakan multimedia interaktif berdasarkan informasi yang telah didapatkan dari tahap analisis, (3) Pengembangan, merupakan tahap dilakukan pengembangan produk multimedia interaktif permainan aku dan hewan sesuai dengan desain yang telah dibuat terdapat beberapa tahapan yaitu, tahap pengembangan produk, tahap validasi dilaksanakan oleh ahli bidang terkait, dan tahap revisi dilakukan berdasarkan saran dari ahli, (4) Implementasi, merupa-kan tahap uji coba ke subjek uji coba 44 orang guru dengan rincian uji coba kelompok kecil dengan subjek 8 orang guru dan uji coba kelompok kecil dengan subjek 36 orang guru, (5) Evaluasi, dilakukan dengan mengolah hasil dari validasi ahli bidang terkait dan subjek uji coba hal ini dilakukan untuk mengetahui tingkat kelayakan multimedia inter-aktif permainan aku dan hewan yang telah dikembangkan. Selain itu juga dipaparkan kelebihan, kekurangan serta spesifikasi multimedia interaktif permainan aku dan hewan.

Instrumen yang digunakan peneliti dalam pengembangan per-mainan aku dan hewan menggunakan multimedia interaktif ini menggunakan kuisioner, diberikan kepada guru pada uji coba kelompok kecil dan uji kelompok besar dari guru yang ada di 8 sekolah jenjang Taman Kanak-kanak (TK) di Kabupaten Malang yang digunakan untuk data kuantitatif. Sedangkan data kualitatif diperoleh dari tinjauan, saran, dan evaluasi para ahli.

Jenis data yang diperoleh adalah data kualitatif dan kuantitatif. Data kualitatif diperoleh dari tinjauan, saran, dan evaluasi para ahli. Data kuantitatif diperoleh melalui pengisian pernyataan yaitu data dari: hasil evaluasi satu orang ahli pendidikan anak usia dini, hasil evaluasi satu orang ahli permainan, hasil evaluasi satu orang ahli media, serta data dari pengisian kuisioner oleh guru pada hasil uji coba kelompok kecil dan kelompok besar, yang bertujuan un-tuk mengetahui kebutuhan produk yang akan dikembangkan.

Subjek penelitian dan pe-ngembangan yang terlibat dalam pengembangan ini adalah: Subjek penelitian awal (analisis kebutuhan) 44 orang guru dari 8 sekolah Taman Kanak-kanak (TK) di Kabupaten Malang. Subyek evaluasi ahli terdiri dari beberapa ahli yaitu: 1 orang ahli pendidikan anak usia dini, 1 orang ahli permainan, dan 1 orang ahli media. Subjek uji coba kelompok kecil adalah dengan subyek 8 guru dari masingmasing sekolah diambil 1 dan dipilih secara acak. Subyek uji coba lapangan kelompok besar dilakukan pada 36 guru dari 8 sekolah.

Teknik analisis data yang digunakan dalam penelitian dan pengembangan permainan aku dan hewan menggunakan multimedia interaktif untuk guru anak usia dini adalah teknik analisis deskriptif kualitatif dan kuantitatif. (a) Data kualitatif diperoleh berdasarkan tin-jauan, saran, dan evaluasi para ahli, (b) Sedangkan Data kuantitatif dipe-roleh dari hasil pernyataan para ahli yang bertujuan untuk penyem-purnaan produk, serta data hasil uji coba kelompok kecil dan serta hasil uji coba kelompok besar dengan menggunakan pengisian kuisioner oleh guru.

Teknik yang digunakan untuk menganalisis data kuantitatif diper oleh dari hasil kuisioner. Untuk mempermudah kesimpulan hasil ana-lisis persentase, hasil data yang diperoleh kemudian digolongkan sesuai dengan persentase yang diperoleh. Analisis kualitatif diguna kan untuk menganalisis hasil pe-ngumpulan data yang diperoleh dari analisis kebutuhan melalui pe-nyebaran angket analisis kebutuhan, Analisis deskriptif kuantitatif yang berupa persentase diguna- 
kan untuk menganalisis hasil uji ahli, uji coba kelompok kecil, dan uji coba ke-lompok besar.

Sedangkan untuk teknik pemaknaan data peneliti meng gunakan analisis persentase yang terdapat pada tabel berikut:

Tabel 1. Kriteria Persentase

\begin{tabular}{lll}
\hline No & Persentase (\%) & Kategori \\
\hline 1 & $0-20 \%$ & Kurang Sesuai \\
2 & $21 \%-40 \%$ & Kurang \\
3 & $41 \%-60 \%$ & Cukup \\
4 & $61 \%-80 \%$ & Baik \\
5 & $81 \%-100 \%$ & Sangat Baik \\
\hline
\end{tabular}

(Sumber: Arikunto 2009:44)

\section{HASIL}

Berdasarkan hasil dari peng umpulan data yang diperoleh dari hasil analisis kebutuhan, evaluasi ahli dan uji coba akan disajikan pada bagian ini. Evaluasi produk dilakukan oleh 3 orang ahli yaitu: 1 ahli pendidikan anak usia dini, 1 ahli permainan, dan 1 ahli media. Data uji coba terdiri dari uji coba kelompok kecil dan uji coba kelompok besar yang diperoleh dari guru anak usia dini dari 8 sekolah Taman Kanak-kanak (TK) di Kabupaten Malang dengan cara mengisi kuesioner yang telah disediakan oleh peneliti.

Berdasarkan hasil analisis ke-butuhan kepada 44 orang guru di 8 sekolah Taman Kanak-kanak (TK) di Kabupaten Malang diperoleh hasil: (1) $100 \%$ menjawab menggunakan kurikulum 2013 dan 0\% menjawab tidak menggunakan kurikulum 2013 , 2) $33 \%$ menjawab permainan yang selama ini dilakukan menarik dan $67 \%$ menjawab tidak menarik, 3) $100 \%$ menjawab gerak tubuh khususnya hewan disampaikan di TK dan $0 \%$ menjawab tidak disampaikan di TK, 4) $28 \%$ menjawab permainan yang diberikan berjalan optimal dan $72 \%$ menjawab tidak optimal, 5) $100 \%$ menjawab setuju jika dikem-bangkan permainan baru yang ber-hubungan dengan gerak tubuh khususnya hewan dan $0 \%$ menjawab tidak setuju, 6) $100 \%$ menjawab di TK pernah menggunakan media dalam proses pembelajaran dan 0\% menjawab tidak, (7) 19\% menjawab di TK pernah menggunakan media berbasis TI (Teknologi Informasi) dan $81 \%$ menjawab tidak pernah, (8) $100 \%$ menjawab setuju jika dikem-bangkan media berbasis $\mathrm{TI}$ (Tek-nologi Informasi) dan 0\% menjawab tidak.

Produk yang dibuat berupa pengembangan permainan aku dan hewan menggunakan multimedia interaktif, dalam multimedia interaktif tersebut berisikan materi tentang: (1) definisi permainan aku dan hewan, (2) tujuan permainan aku dan hewan, (3) alat yang digunakan dalam permainan aku dan hewan, (4) peraturan permainan aku dan hewan, (5) tahapan pelaksanaan permainan aku dan hewan, (6) perkembangan gerak dalam permainan aku dan hewan yang berisikan gerakan non lokomotor, lokomotor, dan manipulatif. Penelitian dan pengem-bangan permainan aku dan hewan menggunakan multimedia interaktif ini juga dilengkapi dengan soal evaluasi.

Evaluasi ahli produk per-mainan aku dan hewan menggunakan multimedia interaktif ini dilakukan oleh tiga orang ahli dibidangnya masing-masing yaitu: ahli pendidikan anak usia dini, ahli permainan, dan ahli media.

Berdasarkan hasil evaluasi ahli pendidikan anak usia dini, setelah ahli media mengevaluasi dan mengamati produk permainan aku dan hewan menggunakan multimedia interaktif, dapat disimpulkan secara keseluruhan diperoleh nilai 188 dari 46 pertanyaan dengan persentase $81,73 \%$ dengan kategori sangat baik digunakan untuk pembelajaran olahraga di Taman Kanak-kanak (TK). Saran-saran ahli pendidikan anak usia dini terhadap hasil pengembangan permainan aku dan hewan menggunakan multimedia interaktif untuk guru anak usia dini sebagai berikut: (1) persiapan materi sangat sempurna, (2) media yang digunakan sangat sesuai, (3) kreatifitas mencipta gerak dasar non lokomotor, manipulasi, dan lokomotor bagus.

Berdasarkan hasil evaluasi ahli permainan, setelah ahli per-mainan mengevaluasi dan menga-mati produk permainan aku dan hewan menggunakan multimedia interaktif, dapat disimpulkan bahwa secara keseluruhan diperoleh nilai 306 dari 70 pertanyaan dengan persentase $87,42 \%$ dengan kategori sangat baik digunakan untuk pembelajaran olahraga di Taman Kanak-kanak (TK). Saran ahli permainan terhadap hasil pengem-bangan permainan 
Ndaru Kukuh M, Pengembangan Permainan Aku dan Hewan Menggunakan Multimedia Interaktif untuk Guru Anak Usia Dini

aku dan hewan menggunakan multimedia interaktif untuk guru anak usia dini sebagai berikut: (1) sebaiknya memberi permainan dari yang sederhana ke yang lebih kompleks.

Berdasarkan hasil evaluasi ahli media, setelah ahli media mengevaluasi dan mengamati produk permainan aku dan hewan menggu-nakan multimedia interaktif, dapat disimpulkan bahwa diperoleh nilai 157 dari 39 pertanyaan dengan persentase $80,51 \%$ dengan kategori baik digunakan untuk pembelajaran olahraga di Taman Kanakkanak (TK). Saran ahli media terhadap hasil pengembangan permainan aku dan hewan menggunakan multimedia interaktif untuk guru anak usia dini sebagai berikut: (1) konsep dan ide kreatif cukup baik, (2) belum optimal pada 2 aspek yaitu audio dan video, (3) silahkan berkolaborasi dengan ahli bidang-bidang terkait (videografi, desain visul, atau yang relevan).

Berdasarkan hasil evaluasi yang dikumpulkan dari ahli pendidi-kan anak usia dini, ahli permainan, ahli media dan guru anak usia dini dari 8 sekolah Taman Kanakkanak (TK) di Kabupaten Malang melalui uji coba kelompok kecil dan uji coba kelompok besar, ada saran pada beberapa tampilan produk yang perlu direvisi agar produk yang dikem-bangkan lebih sempurna dan lebih optimal,

Berikut adalah ringkasan revi-si berdasarkan saran dari para ahli adalah sebagai berikut: (1) saran dari ahli permainan adalah permainan diusahakan dari yang sederhana ke yang lebih kompleks, (2) saran dari ahli pendidikan anak usia dini adalah persiapan materi sangat sempurna, media yang digunakan sangat sesuai, kreatifitas mencipta gerak dasar sangat sesuai, (3) saran dari ahli media adalah sediakan button mute (matikan suara), kualitas video perlu diperbaiki: camera shake, underlight, focus dan editing. Silahkan berkolaborasi dengan bidang terkait.

Kegiatan uji coba kelompok kecil dilaksanakan pada bulan sep-tember 2016, Responden uji coba kelompok kecil berjumlah 8 orang guru diambil 1 dari masingmasing sekolah dan dipilih secara acak. Berdasarkan hasil uji coba kelompok kecil dapat disimpulkan bahwa produk pengembangan permainan aku dan hewan menggunakan multimedia interaktif untuk guru anak usia dini mendapatkan skor 1158 dari 36 pertanyaan dengan mendapatkan persentase sebesar $80,41 \%$, dengan kategori baik sehingga dapat digu-nakan pada uji coba selanjutnya pada uji coba kelompok besar.

Kegiatan uji coba kelompok besar dilaksanakan pada bulan September sampai Oktober 2016 dengan, responden uji coba kelompok besar berjumlah 36 guru dari 8 sekolah Taman Kanak-kanak (TK) di Kabupaten Malang. Berdasarkan hasil uji coba kelompok besar dapat disimpulkan bahwa pengembangan permainan aku dan hewan menggunakan multimedia interaktif untuk guru anak usia dini mendapatkan nilai 5680 dari 36 pertanyaan dengan persentase sebesar $87,65 \%$ dengan kategori sangat baik sehingga dapat digunakan pada pembelajaran olahraga di Taman Kanak-kanak (TK).

\section{PEMBAHASAN}

Produk yang dikembangkan adalah permainan aku dan hewan menggunakan multimedia interaktif untuk guru anak usia dini. Pengem-bangan permainan ini berisi tentang gerak dasar anak usia 5-6 tahun terdiri dari 20 jenis gerakan yang dibagi menjadi gerak dasar non lokomotor, lokomotor, dan manipulatif yang sesuai dengan teori gerak dasar anak usia 5-6 tahun dari teori Gallahue (1996:26-28). Dalam teori-nya Gallahue menjelaskan bahwa teori gerak dasar anak usia 5-6 tahun terdiri dari berlari, meloncat, melom-pat, berderap, berpacu, melempar, menendang, menyerang, keseimbangan dinamis, keseimbangan sta-tis, dan gerakan axial yang keseluruhan dikelompokkan menjadi gerak dasar non lokomotor, lokomotor, dan manipulatif. Hal ini juga sejalan dengan teori kinestetis jasmani dari Yus (2010:70) yang menjelaskan bahwa dimensi pengembangan dan kecerdasan anak usia 5-6 tahun adalah melempar, menangkap, lon-cat, lompat, berlari zigzag, menye-pak, dan berlari dengan seimbang, yang didukung dengan kurikulum 2013 Pendidikan Anak Usia Dini (PAUD) KI-4 pada KD 4.8 yang mengambil tema hewan sehingga permainan yang dihasilkan berupa gerak dasar non lokomotor, loko-motor, dan manipulatif menirukan hewan. Isi permainan dirangkai de-ngan mudah sehingga guru 
anak usia dini mudah memahami dan nantinya dapat memunculkan ketertarikan pada anak didik saat materi menirukan gerakan hewan tersebut diberikan. Dengan menggunakan multimedia interaktif berupa Autoplay Media Studio yang memiliki karakteristik membuat dan mengga-bungkan teks, grafik, audio, gambar bergerak (video dan animasi) dengan menggabungkan link dan tool yang memungkinkan pemakai untuk melakukan navigasi, berinteraksi, berkreasi dan berkomunikasi baik dalam konteks face to face, offline konteks, maupun online konteks (Darmawan, 2012:53). Hal tersebut juga diungkapkan oleh Dwiyogo (2008:92) bahwa multimedia interaktif merupakan sistem media penyampaian yang menyajikan materi video rekaman dengan pengendalian komputer kepada penonton yang tidak hanya mendengar dan melihat video dan suara, tetapi juga memberikan respon yang aktif dan respon itu yang menentukan kecepatan dan sekuensi penyajian.

Dengan menggunakan multi-media interaktif, permainan aku dan hewan yang dikembangkan memiliki kelebihan memperjelas penyajian pesan agar tidak terlalu bersifat verbalistis (dalam bentuk kata-kata tertulis atau lisan belaka), menga-tasai keterbatasan ruang, waktu dan daya indera, Penggunaan media secara tepat dan bervariasi dapat mengatasi sikap pasif anak didik yaitu menimbulkan kegairahan bela-jar, memungkinkan interaksi yang lebih langsung antara anak didik dengan lingkungan dan kenyataan, memungkinkan anak didik belajar sendiri-sendiri menurut kemampuan dan minatnya, memberikan solusi bila latar belakang lingkungan guru dengan siswa berbeda, dalam hal ini kemampuan media memberikan perangsang yang sama, memper-samakan pengalaman, menimbulkan persepsi yang sama (Sadiman, dkk 1986:17). Kelemahan dari produk yaitu dalam pengoperasiannya harus menggunakan komputer.

Pembuatan produk Pengem-bangan permainan aku dan hewan menggunakan multimedia interaktif berupa autoplay media studio ini tentu melalui proses sehingga memungkinkan adanya kesalahan dan kekurangan. Untuk memperoleh produk yang berkualitas, diperlukan faktor-faktor pendukung pula. Pengalaman peneliti merupakan faktor utama yang berdampak pada kualitas produk yang dihasilkan kurang maksimal. Pengambilan video dan pencahayaan yang tepat memerlukan keterampilan tersendiri. Selain itu, munculnya hal-hal non-teknis di lapangan saat pembuatan produk awal menjadi tantangan tersendiri bagi peneliti. Maka dari itu produk yang dikem-bangkan mulai dari rancangan produk hingga produk ini terselesaikan masih memerlukan beberapa revisi untuk mendapatkan produk yang maksimal. Sebagai upaya memak-simalkan produk yang dikembangkan dalam pembuatan produk ini memerlukan evaluasi dari beberapa ahli yaitu: 1 ahli pendidikan anak usia dini, 1 ahli permainan, dan 1 ahli media.

Maka validasi ahli pendidikan anak usia dini dilakukan oleh kepala sekolah TK Kemala Bhayangkari 12 yaitu Hj. Sribawanik, S.Pd dengan 46 instrumen. Dalam setiap pernyataan tersebut mempunyai skor tersendiri yang diberikan oleh ahli pendidikan anak usia dini, skor total yang diperoleh untuk produk pengem-bangan permainan aku dan hewan menggunakan multimedia interaktif untuk guru anak usia dini. Ahli pendi-dikan anak usia dini menyatakan bahwa: (1) persiapan materi sangat sempurna, (2) media yang digunakan sangat sesuai, (3) kreatifitas mencip-ta gerak dasar non lokomotor, manipulasi, dan lokomotor bagus. Berdasarkan hasil evaluasi diperoleh persentase $81,73 \%$ dengan kategori sangat baik.

Evaluasi ahli permainan dila-kukan oleh dosen FIK yaitu I Nengah Sudjana, S.Pd, M.Pd selaku ahli permainan dengan 70 instrumen pada angket evaluasi ahli permainan. Berdasarkan hasil validasi ahli permainan memberikan skor hasil 306 dengan persentase $87,42 \%$ dengan kategori sangat baik. Namun terdapat saran dan masukan yang diberikan oleh ahli permainan produk pengembangan permainan aku dan hewan menggunakan multimedia interaktif untuk guru anak usia dini yaitu permainan diusahakan dari yang sederhana ke yang lebih kompleks

Evaluasi ahli media dilakukan oleh dosen FIP yaitu Eka Pramono Adi, S.I.P, M.Si dalam angket evaluasi ahli media terdapat 39 instrumen. Berdasarkan hasil evaluasi ahli media memberikan skor 157 sehingga produk diperoleh persentase 
Ndaru Kukuh M, Pengembangan Permainan Aku dan Hewan Menggunakan Multimedia Interaktif untuk Guru Anak Usia Dini

$80,51 \%$ dengan kategori baik dan layak digunakan. Meskipun produk dinyatakan baik oleh ahli media, produk tetap ada saran dan masukan dari ahli media terhadap hasil pengem bangan permainan aku dan hewan menggunakan multimedia interaktif untuk guru anak usia dini yaitu: (1) konsep dan ide kreatif cukup baik, (2) belum optimal pada 2 aspek yaitu audio dan video, (3) silahkan berkolaborasi dengan ahli bidang-bidang terkait (videografi, desain visual, atau yang relevan).

Dapat disimpulkan bahwa produk pengembangan permainan aku dan hewan menggunakan multimedia interaktif untuk guru anak usia dini dapat digunakan sebagai media efektif pada pembelajaran olahraga pada tema hewan di sekolah Taman Kanakkanak (TK). Berdasarkan hasil evaluasi para ahli, produk dapat dijadikan media pembelajaran yang menunjang pada tujuan pembelajaran kurikulum 2013.

Pada produk ini juga mempunyai beberapa keunggulan atau kelebihan antara lain: 1) Isi permainan dirangkai dengan mudah sehingga guru anak usia dini mudah memahami dan nantinya dapat memunculkan ketertarikan pada anak didik saat materi menirukan gerakan hewan tersebut diberikan 2) Dengan menggunakan multimedia interaktif berupa Autoplay Media Studio yang memiliki karakteristik membuat dan menggabungkan teks, grafik, audio, gambar bergerak (video dan animasi) dengan menggabungkan link dan tool yang memungkinkan pemakai untuk melakukan navigasi, berinteraksi, berkreasi dan berkomunikasi baik dalam konteks face to face, offline konteks, maupun online konteks.

Terdapat 2 uji coba kelompok yang dilakukan yaitu uji coba kelompok kecil dan uji coba kelompok besar, pada tahapan ini produk akan diuji cobakan pada guru anak usia dini dari 8 sekolah Taman Kanak-kanak (TK) terdapat 36 kuisioner yang diberikan agar produk pengembangan permainan aku dan hewan menggunakan multimedia interaktif untuk guru anak usia dini ini dapat lebih baik dan bermanfaat bagi guru dan anak didik nantinya.

Uji coba kelompok kecil ini dilakukan pada bulan September yang dilakukan pada 8 orang guru anak usia dini masing-masing 1 guru dari tiap sekolah dipilih secara acak , saat uji coba kelompok kecil guru mengamati dan mengoperasikan multimedia interaktif permainan aku dan hewan dan memberikan tangga-pan berupa kuisioner yang terdapat pada angket tanggapan yang ber-tujuan untuk mengetahui kelayakan produk pengembangan permainan aku dan hewan meng-gunakan multimedia interaktif untuk guru anak usia dini dengan men-dapatkan skor hasil 1158 dari 36 pertanyaan dengan mendapatkan persentase sebesar $80,41 \%$, dengan kategori baik dan produk dapat dilanjutkan untuk uji coba kelompok besar.

Uji coba kelompok besar ini dilakukan pada bulan September-Oktober yang dilakukan pada 36 orang guru anak usia dini masing-masing dari 8 sekolah, saat uji coba kelompok besar guru mengamati dan mengoperasikan multimedia interaktif permainan aku dan hewan dan memberikan tanggapan berupa kuisioner yang terdapat pada angket tanggapan yang bertujuan untuk mengetahui kelayakan produk pengembangan permainan aku dan hewan menggunakan multimedia interaktif untuk guru anak usia dini dengan mendapatkan skor hasil 5680 dari 36 pertanyaan dengan per-sentase sebesar $87,65 \%$ dengan kategori sangat baik sehingga dapat digunakan pada pembelajaran olah-raga di Taman Kanak-kanak (TK).

Dari hasil kajian penelitian sebelumnya oleh Bachtiar (2008) tentang pengembangan model per-mainan berbasis kecerdasan kines-tetik untuk taman kanak-kanak kelas B di TK Negeri pembina I Kota Malang dan hasilnya pada uji coba kelompok kecil diperoleh persentase 87,92 sedangkan pada uji coba kelompok besar diperoleh persentase $92,08 \%$ hal tersebut menunjukkan bahwa model permainan dapat digunakan sebagai upaya mengembangkan kecerdasan kinestetik anak kelas B di TK Neger Pembina I Kota Malang. Penelitian serupa juga pernah dilakukan oleh Fantiro (2008) tentang pengembangan model per-mainan untuk meningkatkan kecer-dasan kinestetik siswa taman kanak-kanak negeri pembina kecamatan kepanjen kabupaten malang dan hasilnya pada uji coba kelompok besar diperoleh persentase 91,19\% untuk kelompok $A$ dan $92,61 \%$ untuk kelompok $B$ hal tersebut menunjukkan bahwa model permainan yang dikembangkan dapat dijadikan alter-natif untuk pembelajaran khususnya kecerdasan kinestetik. Selain penelitian yang 
dilakukan oleh Bachtiar dan Fantiro, penelitian serupa juga pernah dilakukan oleh Dwi W (2005) tentang pengembangan modul per-mainan gerak motorik kasar bagi guru TK Dharma Wanita di desa pringu kecamatan bululawang kabu-paten malang dan hasilnya pada uji coba pengguna: (1) aspek kegunaan diperoleh rata-rata 3,58; (2) pada aspek ketepatan diperoleh ratarata 3,375; (3) aspek keefektifan diperoleh ratarata 3,16 ; (4) aspek keterlaksanaan diperoleh rata-rata 3,46 ; (5) aspek kemenarikan diperoleh rata-rata 3,25 hal tersebut menunjukkan bahwa buku modul permainan gerak motorik kasar sangat berguna, mudah, menarik dan akurat untuk dijadikan sebagai media pembelajaran perma-inan TK.

Kesimpulan dari hasil penelitian sebelumnya dan penelitian yang dilakukan adalah pengembangan permainan yang dikembangkan dapat digunakan sebagai media untuk pembelajaran di TK khususnya ke-cerdasan kinestetis.

\section{KESIMPULAN}

Berdasarkan hasil Evaluasi ahli, uji coba kelompok kecil dan kelompok besar yang melibatkan 44 guru anak usia dini dari 8 sekolah Taman Kanak-kanak (TK) di Kabupaten Malang, hasil penelitian dapat disimpulkan bahwa produk permainan aku dan hewan menggunakan multimedia interaktif untuk guru anak usia dini memiliki kesesuaian, ketepatan, ke-menarikan, dan kemudahan untuk dipelajari, dikuasai, dan di praktikkan.

\section{SARAN}

Produk pengembangan ini adalah pengembangan permainan aku dan hewan menggunakan multimedia interaktif berupa autoplay media studio yang dapat digunakan sebagai rujukan oleh guru anak usia dini untuk proses pembelajaran di jenjang Pendidikan Anak Usia Dini (PAUD), Dalam memanfaatkannya sangat perlu pertimbangan situasi, kondisi dan sarana prasarana. Untuk memperoleh tujuan yang diharapkan maka guru anak usia dini diharapkan untuk mampu menguasai materi permainan aku dan hewan terlebih dahulu sebelum disampaikan pada anak didik,

Sebelum disebarluaskan sebaiknya produk ini dikaji kembali dan disesuaikan dengan keadaan sasaran yang ingin ditinjau, Sebelum disebarluaskan sebaiknya produk ini disusun kembali menjadi lebih sempurna, baik itu tentang kemasan tampilan maupun isi dari materi produk yang dikembangkan, Sebelum disebarluaskan sebaiknya disosialisasikan kepada pihak-pihak terkait seperti guru anak usia dini dan orang-orang yang berkecimpung di pendidikan anak usia dini lainnya untuk memperoleh pengakuan dan perijinan untuk penerapan permainan aku dan hewan berbasis multimedia interaktif,

Hasil pengembangan ini hanya sampai tersusun sebuah produk, belum sampai tingkat efektivitas produk yang dikembangkan jadi sebaiknya dilanjutkan penelitian menganai efektivitas produk yang dikembangkan, Pada pembe-lajaran permainan aku dan hewan guru anak usia dini harus secara detail memberikan contoh kepada anak didik tentang berbagai gerakan yang ada dalam multimedia interaktif berupa autoplay media studio.

\section{DAFTAR RUJUKAN}

Arikunto, Suharsini. 2009. Manajemen Penelitian. Jakarta: PT. Rineka Cipta

Baharom, Masri dkk. 2014. International Educative Research Foundation and Publisher. (online), (http://www.ijier.net/assets/grossmotor-development-level-of-thechildren-ijier.net-vol-2-11-14.pdf), diakses 21 Januari 2016.

Darmawan, Deni. 2011. Inovasi Pendidikan. Bandung: PT. Remaja Rosdakarya.

Desmita. 2005. Psikologi Perkembangan. Bandung: PT. Remaja Rosdakarya.

Dwiyogo, Wasis D. 2008. Aplikasi Teknologi Pembelajaran Media Pembelajaran Penjas \& Olahraga. Malang: Fakultas 
Ndaru Kukuh M, Pengembangan Permainan Aku dan Hewan Menggunakan Multimedia Interaktif untuk Guru Anak Usia Dini

Ilmu Pendidikan Universitas Negeri Malang

Gallahue, David L. 1996. Developmental Physical Education for Today's Children. Indiana University and The National Institute for Fitnes and Sport

H, M. Furqon. 2006. Mendidik Anak Dengan Bermain. Surakarta: Universitas Sebelas Maret Surakarta.

Huang, Rita. 2013. School of Education eJournal. (online), (http://www. manukau.ac.nz/data/assets/pdf file/0010/119935/02-Huang-stafffinal.pdf), diakses 21 Januari 2016.

Lee, William W. And Owens, Diana L. 2004. Multimedia-Based Instructional Design. San Fransisco, USA: Pfeiffer an impirint of willey.

Muhammad, Fadhilah. 2012. Desain Pembelajaran PAUD. Jogjakarta: $\mathrm{Ar}$ ruzz Media.

Mursid. 2015. Belajar dan Pembelajaran PAUD. Bandung: PT. Remaja Rosdakarya.

Monks, F.J., dkk. 1982. Psikologi Perkembangan Pengantar Dalam Berbagai Bagiannya. Yogyakarta. Gadjah Mada University Press.

Peraturan Menteri Pendidikan dan Kebudayaan Republik Indonesia No. 146 Tahun 2014 tentang Kurikulum 2013 Pendidikan Anak Usia Dini. 2014.Jakarta

Sadiman, Arief S. dkk. 1986. Media Pendidikan Pengertian, Pengembangan, dan Pemanfaatannya. Jakarta: PT. Rajagrafindo Persada.

Smith, Peter K. 2013. Encyclopedia on Early Childhood Development. (online), (http://www.child-encyclopedia.com/ Pages/PDF/play.pdf), diakses 21 Januari 2016.

Thobroni, M. \& Mumtaz, Fairuzul. 2011. Mendongkrak Kecerdasan Anak
Melalui Bermain dan Permainan. Jogjakarta: Kata Hati.

Yus, Anita. 2010. Model Pendidikan Anak Usia Dini. Jakarta: Kencana Prenada Media Grup.

Yusuf, Syamsu. 2000. Psikologi Perkembangan Anak \& Remaja. Bandung: PT. Remaja Rosdakarya. 